DOI https://doi.org/10.18551/rjoas.2017-05.32

\title{
GROWTH AND YIELD CHARACTERISTICS OF THREE SHALLOT VARIETIES AFFECTED BY PHOSPHATE FERTILIZER DOSAGES ON ULTISOL
}

\author{
Irianto* \\ Faculty of Agriculture, Jambi University, Indonesia \\ Yakup, Harun M.U., Susilawati \\ Faculty of Agriculture, Sriwijaya University, Indonesia \\ *E-mail: irianto@unja.ac.id
}

\begin{abstract}
This research aims to obtain growth and yield characteristics of shallot due to three shallot varieties and phosphate fertilizer dosages on Ultisol. The experiment was conducted from July to September 2015 in Horticulture Main Seed Development Centre in Muaro Jambi district. Randomized block design used was arranged with two factors. The first factor was varieties e.i. Bima Brebes, Bauji, and Bangkok. The second factor was dosages of phosphate fertilizer e.i. $0 ; 125 ; 250 ; 375 \mathrm{~kg} \mathrm{P}_{2} \mathrm{O}_{5}$ ha $^{-1}$. The growth and yield characteristics of shallot were different for each shallot variety and dosage of phosphate fertilizer. Bangkok variety had the highest Net Assimilation Rate (NAR), Specific Leaf Weight (SLW), bulb to leaf dry weight ratio and bulbs number. Bima Brebes variety had the highest Leaf Area Index (LAl), Crop Growth Rate (CGR), bulbs diameter, and bulbs weight whereas Bauji variety only had the highest Leaf Area Ratio (LAR). Optimum dosage of phosphate was different for each variety. The dosage of $375 \mathrm{~kg} \mathrm{P}_{2} \mathrm{O}_{5}$ ha $^{-1}$ at Bangkok variety of bulbs weight increased linearly. The highest weight of Bima Brebes bulbs variety was obtained with $21.62 \mathrm{~g}$ per hill at an optimum dosage of $246.11 \mathrm{~kg} \mathrm{P}_{2} \mathrm{O}_{5} \mathrm{ha}^{-1}$.
\end{abstract}

\section{KEY WORDS}

Growth and yield, phosphate fertilizer, shallot varieties, ultisol.

Shallot is classified as strategic and prime commodity for Indonesia which continuously gains government attention in order to be developed through the productivity increase and expansion of plant area. This is appropriate with the increase of shallot demand as the result of population growth and shallot used in daily life which cannot be compensated by the other commodities. According to the Agricultural Information System Data Center (2015) showed that the average of shallot consumption in the Indonesian year 2014 was $2.49 \mathrm{~kg} / \mathrm{capita} / \mathrm{year}$ and a projection in 2019, it is going to increase to 2.55/kg/capita/year. During 2010-2014, there was significant fluctuation number of harvest areas and shallot products, and an average of national shallot yield in 2014 just reached 10.22 tons ha ${ }^{-1}$ (General Directorate of Horticulture, 2015) which was not relevant to the description of some shallot varieties whose potential yield more than 13 tons $\mathrm{ha}^{-1}$. Due to the facts, it still requires the best effort to escalate shallot productivity for domestic supply and export.

One of the factors that should be examined in order to enhance yield and productivity of shallot is optimized the utilization of production facilities, such using proper superior varieties. Several superior local varieties have been available and acceptable to be a range of options to reduce reliance on the use of import seeds. However, each shallot variety has distinct ability to adapt as it needs planting test in the other regions. Idhan et al. (2015) conducted a research that showed the yield of shallot was far below the national average which was Bauji variety yield as much as 8.5 tons ha ${ }^{-1}$. Brebes variety 3.5 tons ha ${ }^{-1}$, and Bangkok variety 4.0 tons ha ${ }^{-1}$.

Besides the use of appropriate prime varieties, to increase yield shallot has to approach the lack of soil fertility, one of the nutrients that is often to be a limit factor for plant growth is phosphorus (P). P element is provided for the plant in soil as ionic form, almost as 
$\mathrm{H}_{2} \mathrm{PO}_{4}{ }^{-}$and $\mathrm{HPO}_{4}{ }^{-}$. $\mathrm{P}$ element is widely traded as phosphate fertilizer containing the $\mathrm{P}_{2} \mathrm{O}_{5}$ compound. $\mathrm{P}$ element is essential macronutrient which is required for plant growth and development. It influences the number and quality of yield. $P$ element has a function as an energy resource in ATP formed necessarily for nutrient absorption, photosynthesis and photosynthate translocation of the leaves as sources, as well as biosynthesis other macromolecules that will accumulate as a food reserve and organ structure the new plants. $\mathrm{P}$ element can be a crucial part of macromolecule as phospholipid and nucleic acid.

The availability of $P$ element for plants is often limited since the majority of the elements are insoluble form. Rashmi et al. (2015) stated that Langmuir and Freundlich's model was acceptable to describe phosphate ion absorption on soil colloid surface where the presence of clay. Al and Fe elements guided the capacity of ion absorption by soil colloid. As on Ultisol, a plenty of $\mathrm{P}$ elements bound with $\mathrm{Al}$ and $\mathrm{Fe}$ elements. The phosphate ion adsorption behavior can be used to measure the effectiveness of the $P$ element needed and to supply optimal $\mathrm{P}$ element, to yield maximum plant production require phosphate fertilizer on a higher dosage.

Metabolic processes in the plants, especially anabolism, are influenced by the availability of $P$ element as an energy source in the form of ATP. Hence, $P$ element deficiency has the ability to affect the growth and development of the plant. Nevertheless, each plant response to resilience and mechanism of adaptation are varying, and this can be used as consideration to decide an exact variety of plant that is tolerant to the lack of $P$ element. Simon et al. (2014) assumed each onion variety has a different response to different phosphate fertilizer. Navies' variety shows greater growth and yield than Bombe Red variety, and Navies onion variety has the highest bulbs yield with phosphate fertilizer on dosage $46 \mathrm{~kg} \mathrm{P}_{2} \mathrm{O}_{5} \mathrm{ha}^{-1}$.

Shallot also gives reaction to phosphate fertilizer. Sumarni et al. (2012) research showed that giving phosphate fertilizer in soil with high $\mathrm{P}$ status $\left(>26 \mathrm{ppm} \mathrm{P}_{2} \mathrm{O}_{5}\right)$ could still increase bulbs yield and Bangkok variety had the highest yield with phosphate fertilizer on dosage $126.5 \mathrm{~kg} \mathrm{P}_{2} \mathrm{O}_{5}$ ha $^{-1}$. While on $\mathrm{P}$ status low (<15 ppm $\left.\mathrm{P}_{2} \mathrm{O}_{5}\right)$ and medium (16-25 ppm $\mathrm{P}_{2} \mathrm{O}_{5}$ ) gave Phosphate fertilizer on dosage $240 \mathrm{~kg} \mathrm{P}_{2} \mathrm{O}_{5}$ ha $^{-1}$ showed a linear increase of bulbs yield.

Attempt to improve yield and production of shallot in Indonesia, advance strategy for shallot in different region or location, especially in acid land, is usually taken along with phosphate fertilizer at uniform dosage or general recommendation dosage. Therefore, it does not provide exact result yet and needs application improvement of phosphate fertilizer. Furthermore, the appropriate phosphate fertilizer dosage for each shallot variety in a specific location has to be examined in order to obtain optimal shallot production. This research aims to obtain growth and yield characteristics of shallot due to three shallot varieties and phosphate fertilizer dosages on Ultisol.

\section{MATERIALS AND METHODS OF RESEARCH}

The research was conducted from July to September 2015 in Horticulture Main Seed Development Centre of Muaro Jambi district - Indonesia on Ultisol, pH 4.07, N-total 0.19 (low), available P 3.19 ppm (very low), $\mathrm{K}_{\text {-exch }} 0.32 \mathrm{me} 100 \mathrm{~g}^{-1}$ (low), Al $\mathrm{I}_{\text {-exch }} 1.44, \mathrm{H}_{\text {-exch }} 0.58$. Material used was three varieties shallots which consist in Bima Brebes, Bauji, and Bangkok varieties, dolomite, Urea fertilizer $(46 \% \mathrm{~N})$, TSP $\left(46 \% \mathrm{P}_{2} \mathrm{O}_{5}\right), \mathrm{KCl}\left(60 \% \mathrm{~K}_{2} \mathrm{O}\right)$, chicken manure, Furadan 3GR insecticide/ nematicide (active ingredient: Carbofuran 3\%), Dithane M-45 80 WP fungicide (active ingredient: Mancozeb 80\%) and Curacron insecticide (active ingredient: Profenofos $500 \mathrm{gL}^{-1}$ ).

This experiment used Randomized block design arranged in factorial. There were two factors of treatment, the first was shallot varieties, i.e. Bima Brebes, Bauji, Bangkok; and the second was phosphate fertilizer dosages, i.e. 0; 125; 250; $375 \mathrm{~kg} \mathrm{P}^{2} \mathrm{O} 5 \mathrm{ha}^{-1}$. Each treatment combination was repeated 3 times.

Shallot bulbs had been stored for 3 months. Before the shallot bulbs were planted, the $1 / 4$ bottom edge of it was cut to keep initial growth uniformity. The land was plowed at $\pm 30 \mathrm{~cm}$ 
depth and then given dolomite 1.5 ton ha ${ }^{-1}$. The plots were built at size $120 \mathrm{~cm} \times 180 \mathrm{~cm}$, distance in a block was $30 \mathrm{~cm}$, between blocks, were $50 \mathrm{~cm}$, and height was $30 \mathrm{~cm}$. Each shallot bulb planting at $15 \mathrm{~cm} \times 20 \mathrm{~cm}$ distance, done by embed the bulb flush to the ground and the buds facing up.

Basic fertilizers used were 10 tons ha $^{-1}$ chicken manure and phosphate fertilizer at treatment dosages. These were given seven days before planting, mixed with the soil. Other fertilizers used were $250 \mathrm{~kg} \mathrm{~N} \mathrm{ha}^{-1}\left(544 \mathrm{~kg} \mathrm{Urea} \mathrm{ha}^{-1}\right)$ and $100 \mathrm{~kg} \mathrm{~K}_{2} \mathrm{O} \mathrm{ha}{ }^{-1}\left(167 \mathrm{~kg} \mathrm{KCl} \mathrm{ha}^{-1}\right)$, used at 3, 21 and 35 days after planting (DAP), each used at 1/3 dosage.

Watering was done each day for up to 7 days before harvest. Weeds were controlled manually whereas pathogen was conquered chemically used Furadan 3GR insecticide/ nematicide, Dithane M-45 80 WP fungicide and Curacron insecticide at recommendation dosage.

Observation of growth characteristics performed on Net Assimilation Rate (NAR), Leaf Area Ratio (LAR), Specific Leaf Weight (SLW), Leaf Area Index (LAI), Crop Growth Rate (CGR), and bulb to leaf dry weight ratio with destructive plant sample. It performed at 14, 21, 28, 35 and 42 days after planting (DAP). The growth analyses of NAR, LAR, SLW, SLW, LAI, and CGR were carried out following the formulas of Bugbee (1996):

$$
\begin{array}{ll}
N A R=\frac{\left(W_{2}-W_{1}\right)}{\left(T_{2}-T_{1}\right)} \times \frac{\left(\ln L a_{2}-\ln L a_{1}\right)}{\left(L a_{2}-L a_{1}\right)} & L A I=\frac{\left(L a_{2}+L a_{1}\right)}{2} \times \frac{1}{G_{A}} \\
L A R=\frac{\left(L a_{2} / W_{2}+L a_{1} / W_{1}\right)}{2} & C G R=\frac{1}{G_{A}} \times \frac{\left(W_{2}-W_{1}\right)}{\left(T_{2}-T_{1}\right)} \\
S L W=\frac{\left(L w_{2} / L a_{2}+L w_{1} / L a_{1}\right)}{2} &
\end{array}
$$

Where: La: leaf area; Lw: leaf weight; $\mathrm{G}_{A}$ : ground area; $\mathrm{T}$ : time; W: weight. Whereas observation for shallot yield includes bulbs number per hill, an average diameter of bulbs and bulbs weights per hill. Obtained data analyzed using analysis of variance followed by the Least Significant Difference (LSD) test for single factor and Honestly Significant Difference (HSD) for interaction factor ( $p$ 0.05). The optimum dosage of phosphate fertilizer for the yield to produce the highest bulbs weight per hill is determined by regression analysis.

\section{RESULTS AND DISCUSSION}

Growth Characteristics. The result showed there was no interaction between varieties and phosphate fertilizer dosages on Net Assimilation Rate (NAR), Leaf Area Ratio (LAR), Specific Leaf Weight (SLW), Leaf Area Index (LAI), and Crop Growth Rate (CGR). The interaction was only for the bulb to leaf dry weight ratio.

This research defined that NAR was influenced by varieties and phosphate dosages. Bangkok variety had the highest NAR, started at 21-28 to 35-42 days after planting whereas Bauji got the lowest NAR, started at 21-28 to 28-35 days after planting. Phosphate fertilizer dosages influenced NAR at aged 21-28 to 28-35 days after planting; the highest NAR was obtained at $250 \mathrm{~kg} \mathrm{P}_{2} \mathrm{O}_{5} \mathrm{ha}^{-1}$, otherwise, NAR decreased at $375 \mathrm{~kg} \mathrm{P}_{2} \mathrm{O}_{5}$ ha $^{-1}$ (Table 1). Hochberg et al. (2015) found variety affected photosynthesis rate. In addition, Pandey et al. (2015) said NAR was influenced by phosphate application and Li et al. (2016) proved that the increase of NAR was able to enhance leaves capacity as a source.

Lower NAR value in early growth was caused by the young leaves not fully developed and not able to do a maximum photosynthetic activity. Furthermore, NAR value was escalated by the increase of plant aged up to 35-42 DAP due to the accretion of leaves growth and bulbs growth as reproductive organs, shown by the accretion of a bulb to leaf dry weight ratio (Table 6). Bulbs formation and growth was a very strong sink that required a plenty of photosynthates and on optimal conditions, photosynthetic activity of the leaves would run on the blistering way. It was also supported by the shallot leaves not overshadow 
each other. This caused the solar radiation might affect the entire leaves surface. Sridevi and Chellamuthu (2015) also stated that NAR increased in the early stages of reproductive phase.

Table 1 - Net assimilation rate (NAR) of three shallot varieties with different phosphate dosages

\begin{tabular}{lllll}
\hline \multirow{2}{*}{ Treatment } & \multicolumn{4}{c}{$\mathrm{NAR}\left(\mathrm{mg} \mathrm{cm}^{-2} \mathrm{~d}^{-1}\right)$} \\
\cline { 2 - 5 } & $14-21 \mathrm{DAP}$ & $21-28 \mathrm{DAP}$ & $28-35 \mathrm{DAP}$ & $35-42 \mathrm{DAP}$ \\
\hline Bima Brebes & 0.92 & $1.13 \mathrm{~b}$ & $1.46 \mathrm{~b}$ & $1.79 \mathrm{~b}$ \\
Bauji & 0.94 & $0.97 \mathrm{c}$ & $1.27 \mathrm{c}$ & $1.56 \mathrm{~b}$ \\
Bangkok & 1.15 & $1.77 \mathrm{a}$ & $2.28 \mathrm{a}$ & $2.72 \mathrm{a}$ \\
$\mathrm{LSD} \mathrm{5 \%}$ & $\mathrm{ns}$ & 0.092 & 0.120 & 0.241 \\
\hline $0 \mathrm{~kg} \mathrm{ha}^{-1} \mathrm{P}_{2} \mathrm{O}_{5}$ & 0.93 & $1.30 \mathrm{ab}$ & $1.68 \mathrm{ab}$ & 1.99 \\
$125 \mathrm{~kg} \mathrm{ha}^{-1} \mathrm{P}_{2} \mathrm{O}_{5}$ & 0.10 & $1.31 \mathrm{ab}$ & $1.68 \mathrm{ab}$ & 2.04 \\
$250 \mathrm{~kg} \mathrm{ha}^{-1} \mathrm{P}_{2} \mathrm{O}_{5}$ & 1.15 & $1.33 \mathrm{a}$ & $1.72 \mathrm{a}$ & 2.16 \\
$375 \mathrm{~kg} \mathrm{ha}^{-1} \mathrm{P}_{2} \mathrm{O}_{5}$ & 0.92 & $1.22 \mathrm{~b}$ & $1.58 \mathrm{~b}$ & 1.90 \\
LSD 5\% & $\mathrm{ns}$ & 0.106 & 0.139 & $\mathrm{~ns}$ \\
\hline
\end{tabular}

Note: Numbers followed by different letter at each column are significantly different at $p=0.05$; $n s=$ not significant.

This research showed LAR was only influenced by varieties. Bauji had the highest LAR whereas Bangkok had the lowest LAR (Table 2), and LAR value showed leaf area increase for each unit of plant dry weight. Fischer et al. (2012) explained that variety influenced the ratio of leaves to the other plant organs.

LAR expressed leaves capacity as a source, and lower LAR as Bangkok variety had could reduce photosynthate because of lack leaves area where photosynthesis took place, so photosynthesis effectiveness for each unit of leaf area was shown by high NAR (Table 1) less effective to increase total biomass. Alizadeh et al. (2013) found the balance of sourcesink would control photosynthesis and yield. In addition, Fischer et al. (2012) said lack of leaves area in line was going to cut reproductive growth.

Table 2 - Leaf area ratio (LAR) of three shallot varieties with different phosphate dosages

\begin{tabular}{lllll}
\hline \multirow{2}{*}{ Treatment } & \multicolumn{4}{c}{ LAR $\left(\mathrm{cm}^{2} \mathrm{~g}^{-1}\right)$} \\
\cline { 2 - 5 } & 14-21 DAP & $21-28 \mathrm{DAP}$ & $28-35 \mathrm{DAP}$ & $35-42 \mathrm{DAP}$ \\
\hline Bima Brebes & $46.22 \mathrm{~b}$ & $39.15 \mathrm{~b}$ & $33.34 \mathrm{~b}$ & $28.84 \mathrm{~b}$ \\
Bauji & $50.81 \mathrm{a}$ & $45.81 \mathrm{a}$ & $39.19 \mathrm{a}$ & $34.96 \mathrm{a}$ \\
Bangkok & $32.07 \mathrm{c}$ & $25.86 \mathrm{c}$ & $21.73 \mathrm{c}$ & $18.48 \mathrm{c}$ \\
$\mathrm{LSD} \mathrm{5 \%}$ & 2.702 & 2.947 & 2.580 & 2.695 \\
\hline $0 \mathrm{~kg} \mathrm{ha}^{-1} \mathrm{P}_{2} \mathrm{O}_{5}$ & 42.47 & 36.62 & 31.15 & 27.18 \\
$125 \mathrm{~kg} \mathrm{ha}^{-1} \mathrm{P}_{2} \mathrm{O}_{5}$ & 42.67 & 36.69 & 31.24 & 27.34 \\
$250 \mathrm{~kg} \mathrm{ha}^{-1} \mathrm{P}_{2} \mathrm{O}_{5}$ & 42.05 & 35.53 & 30.20 & 26.30 \\
$375 \mathrm{~kg} \mathrm{ha}^{-1} \mathrm{P}_{2} \mathrm{O}_{5}$ & 44.95 & 38.92 & 33.09 & 28.90 \\
LSD 5\% & $\mathrm{ns}$ & $\mathrm{ns}$ & $\mathrm{ns}$ & $\mathrm{ns}$ \\
\hline
\end{tabular}

Note: Numbers followed by different letter at each column are significantly different at $p=0.05$; $n s=$ not significant.

High LAR in early plant growth was caused by a large number of young leaves and accretion of leaves area, so photosynthesis activity not optimal yet and photosynthate was used more for its own growth of the young leaves. Therefore, an increase of leaves area was higher than photosynthate accumulation for the growth of the whole plant. Moreover, the increase of plant age in line with decrease LAR value because an increase of leaves area rate was lower than accumulation dry material for whole plant's parts. It was supported by NAR value increase at early reproductive phase. Hence, dry plant weight increase was higher than leaves area increase. This phenomenon explains plant age increase, especially at the early reproductive phase, the reproductive organ had stronger sink than the other organs include the leaves.

SLW was only affected by variety, whereas phosphate fertilizer dosage did not impact all stages of plant age. Bangkok variety had the highest SLW followed by Bima Brebes, and Bauji had the lowest (Table 3). SLW represented dry weight increase for each leaf area unit. Pankaj et al. (2015) explained different variety demonstrated different dry material 
accumulation, Weraduwage et al. (2015) said, there was a correlation between leaves area accretion and biomass accretion depend on how photosynthate partition between new leaves part and leaves mass.

Table 3 - Specific leaf weight (SLW) of three shallot varieties with different phosphate dosages

\begin{tabular}{lllll}
\hline \multirow{2}{*}{ Treatment } & \multicolumn{4}{c}{ SLW $\left(\mathrm{mg} \mathrm{cm}^{-2}\right)$} \\
\cline { 2 - 5 } & 14-21 DAP & $21-28 \mathrm{DAP}$ & $28-35 \mathrm{DAP}$ & $35-42 \mathrm{DAP}$ \\
\hline Bima Brebes & $5.10 \mathrm{a}$ & $5.23 \mathrm{a}$ & $5.66 \mathrm{a}$ & $5.96 \mathrm{~b}$ \\
Bauji & $4.98 \mathrm{ab}$ & $4.99 \mathrm{~b}$ & $5.40 \mathrm{~b}$ & $5.62 \mathrm{c}$ \\
Bangkok & $4.88 \mathrm{~b}$ & $5.25 \mathrm{a}$ & $5.71 \mathrm{a}$ & $6.17 \mathrm{a}$ \\
$\mathrm{LSD} \mathrm{5 \%}$ & 0.139 & 0.157 & 0.165 & 0.175 \\
\hline $0 \mathrm{~kg} \mathrm{ha}^{-1} \mathrm{P}_{2} \mathrm{O}_{5}$ & 4.98 & 5.16 & 5.59 & 5.92 \\
$125 \mathrm{~kg} \mathrm{ha}^{-1} \mathrm{P}_{2} \mathrm{O}_{5}$ & 4.98 & 5.15 & 5.57 & 5.90 \\
$250 \mathrm{~kg} \mathrm{ha}^{-1} \mathrm{P}_{2} \mathrm{O}_{5}$ & 5.00 & 5.18 & 5.62 & 5.94 \\
$375 \mathrm{~kg} \mathrm{ha}^{-1} \mathrm{P}_{2} \mathrm{O}_{5}$ & 4.97 & 5.14 & 5.57 & 5.91 \\
LSD 5\% & ns & ns & ns & ns \\
\hline
\end{tabular}

Note: Numbers followed by different letter at each column are significantly different at $p=0.05$; $n s=$ not significant.

SLW was lower at the early plant growth because the increase of leaves dry weight was followed by leaves height area increase. The Increase of plant age and leaves affected dry material accumulation in leaves, dominated to increase leaves dry weight and therefore increased SLW. Observation showed SLW had a strong correlation with NAR and LAR which influenced bulbs yield. In order to gain bulbs yield height, the balance of growth characteristics was required. SLW increase had a correlation with NAR increase. This was a contrast with LAR decline. Lower vegetative growth made it less optimal to support reproductive growth. Otherwise, very dominant vegetative growth decreased photosynthate partition for reproductive organ. Fischer et al. (2012) delineated adequate ratio of leaves for reproductive organs were required in order to obtain high number and quality of yield.

LAI for all shallot ages was affected by varieties and phosphate dosages. Bima Brebes variety had the highest LAl whereas between Bauji and Bangkok varieties did not have any difference. The highest LAl was obtained by $250 \mathrm{~kg} \mathrm{ha}^{-1} \mathrm{P}_{2} \mathrm{O}_{5}$ fertilizer dosage and $0 \mathrm{~kg} \mathrm{ha}^{-1}$ $\mathrm{P}_{2} \mathrm{O}_{5}$ fertilizer dosage gave the lowest (Table 4). Kour and Sharma (2016) found LAI increase correlated to the specific pattern of plant growth; it was the cumulative effect of leaves area increase, as the result of number and growth leaves increase.

Shallot canopy shape was upright and the leaves layout did not overshadow, LAI increase would not decrease NAR as each leaf did not compete against sunlight interception. The balance of NAR, LAR, SLW and LAl simultaneously influenced source capacity that controlled sink. Fischer et al. (2012) declared the number and quality of yield required sufficient ratio of leaves to reproductive organs or certain numbers and leaves area. In addition, Li et al. (2016) found source capacity had direct effect to yield and higher source capacity gave higher number and quality of yield.

Table 4 - Leaf area index (LAI) of three shallot varieties with different phosphate dosages

\begin{tabular}{lllll}
\hline \multirow{2}{*}{ Treatment } & \multicolumn{5}{c}{ LAl } \\
\cline { 2 - 5 } & 14-21 DAP & $21-28 \mathrm{DAP}$ & $28-35 \mathrm{DAP}$ & $35-42 \mathrm{DAP}$ \\
\hline Bima Brebes & $0,26 \mathrm{a}$ & $0,29 \mathrm{a}$ & $0,34 \mathrm{a}$ & $0,42 \mathrm{a}$ \\
Bauji & $0,15 \mathrm{c}$ & $0,18 \mathrm{~b}$ & $0,21 \mathrm{~b}$ & $0,26 \mathrm{~b}$ \\
Bangkok & $0,18 \mathrm{~b}$ & $0,20 \mathrm{~b}$ & $0,23 \mathrm{~b}$ & $0,27 \mathrm{~b}$ \\
LSD 5\% & 0,022 & 0,029 & 0,034 & 0,045 \\
\hline $0 \mathrm{~kg} \mathrm{ha}^{-1} \mathrm{P}_{2} \mathrm{O}_{5}$ & $0,16 \mathrm{~b}$ & $0,19 \mathrm{~b}$ & $0,22 \mathrm{~b}$ & $0,27 \mathrm{c}$ \\
$125 \mathrm{~kg} \mathrm{ha}^{-1} \mathrm{P}_{2} \mathrm{O}_{5}$ & $0,18 \mathrm{~b}$ & $0,21 \mathrm{~b}$ & $0,24 \mathrm{~b}$ & $0,30 \mathrm{bc}$ \\
$250 \mathrm{~kg} \mathrm{ha}^{-1} \mathrm{P}_{2} \mathrm{O}_{5}$ & $0,22 \mathrm{a}$ & $0,25 \mathrm{a}$ & $0,29 \mathrm{a}$ & $0,36 \mathrm{a}$ \\
$375 \mathrm{~kg} \mathrm{ha}^{-1} \mathrm{P}_{2} \mathrm{O}_{5}$ & $0,21 \mathrm{a}$ & $0,24 \mathrm{a}$ & $0,28 \mathrm{a}$ & $0,34 \mathrm{ab}$ \\
LSD 5\% & 0,026 & 0,033 & 0,038 & 0,052 \\
\hline
\end{tabular}

Note: Numbers followed by different letter at each column are significantly different at $p=0.05$. 
CGR in entire plant age affected varieties and phosphate fertilizer dosages. Bima Brebes and Bangkok varieties had higher CGR than Bauji. The highest CGR was given by $250 \mathrm{~kg} \mathrm{P}_{2} \mathrm{O}_{5} \mathrm{ha}^{-1}$ dosage and $0 \mathrm{~kg} \mathrm{P}_{2} \mathrm{O}_{5} \mathrm{ha}^{-1}$ dosage gave the lowest (Table 5). Pandey et al. (2015) explained that CGR was influenced by phosphate fertilization and Sopha et al. (2015) added that plant growth analysis was acceptable to be used as guidance to diagnose nutrients level and as a tool to recommend shallot fertilization.

Table 5 - Crop growth rate (CGR) of three shallot varieties with different phosphate dosages

\begin{tabular}{|c|c|c|c|c|}
\hline \multirow{2}{*}{ Treatment } & \multicolumn{4}{|c|}{$\operatorname{CGR}\left(\mathrm{mg} \mathrm{cm}^{-2} \mathrm{~d}^{-1}\right)$} \\
\hline & 14-21 DAP & 21-28 DAP & 28-35 DAP & 35-42 DAP \\
\hline Bima Brebes & $0,23 a$ & $0,33 a$ & $0,50 a$ & $0,74 a$ \\
\hline Bauji & $0,13 b$ & $0,17 b$ & $0,26 \mathrm{~b}$ & $0,39 \mathrm{~b}$ \\
\hline Bangkok & $0,19 a$ & $0,35 a$ & $0,53 a$ & $0,74 a$ \\
\hline LSD $5 \%$ & 0,054 & 0,036 & 0,053 & 0,095 \\
\hline $0 \mathrm{~kg} \mathrm{ha}^{-1} \mathrm{P}_{2} \mathrm{O}_{5}$ & $0,14 \mathrm{~b}$ & $0,24 \mathrm{c}$ & $0,37 \mathrm{c}$ & $0,52 \mathrm{c}$ \\
\hline $125 \mathrm{~kg} \mathrm{ha}^{-1} \mathrm{P}_{2} \mathrm{O}_{5}$ & $0,17 a b$ & $0,27 \mathrm{bc}$ & $0,41 \mathrm{bc}$ & $0,59 \mathrm{bc}$ \\
\hline $250 \mathrm{~kg} \mathrm{ha}^{-1} \mathrm{P}_{2} \mathrm{O}_{5}$ & $0,22 \mathrm{a}$ & $0,32 \mathrm{a}$ & 0,48 a & $0,72 \mathrm{a}$ \\
\hline $375 \mathrm{~kg} \mathrm{ha}^{-1} \mathrm{P}_{2} \mathrm{O}_{5}$ & $0,20 a b$ & $0,30 a b$ & $0,45 a b$ & $0,66 a b$ \\
\hline LSD $5 \%$ & 0,062 & 0,041 & 0,061 & 0,110 \\
\hline
\end{tabular}

Note: Numbers followed by different letter at each column are significantly different at $p=0.05$.

Plant age increase would be followed by the increase of CGR up to 35-42 DAP. Mojaddam and Noori (2015) explained that CGR boosted slightly at early plant growth and increased significantly at next step. The slow increase of CGR at early plant growth occurred due to a numerous of the vegetative meristem, include the leaves not fully developed. CGR increase was faster after maximum leaves area was reached, that was taken along by the use of efficient sunlight. Khayat et al. (2015) explained that CGR increase would be followed by LAI increase and it would reach the maximum value at early reproductive phase.
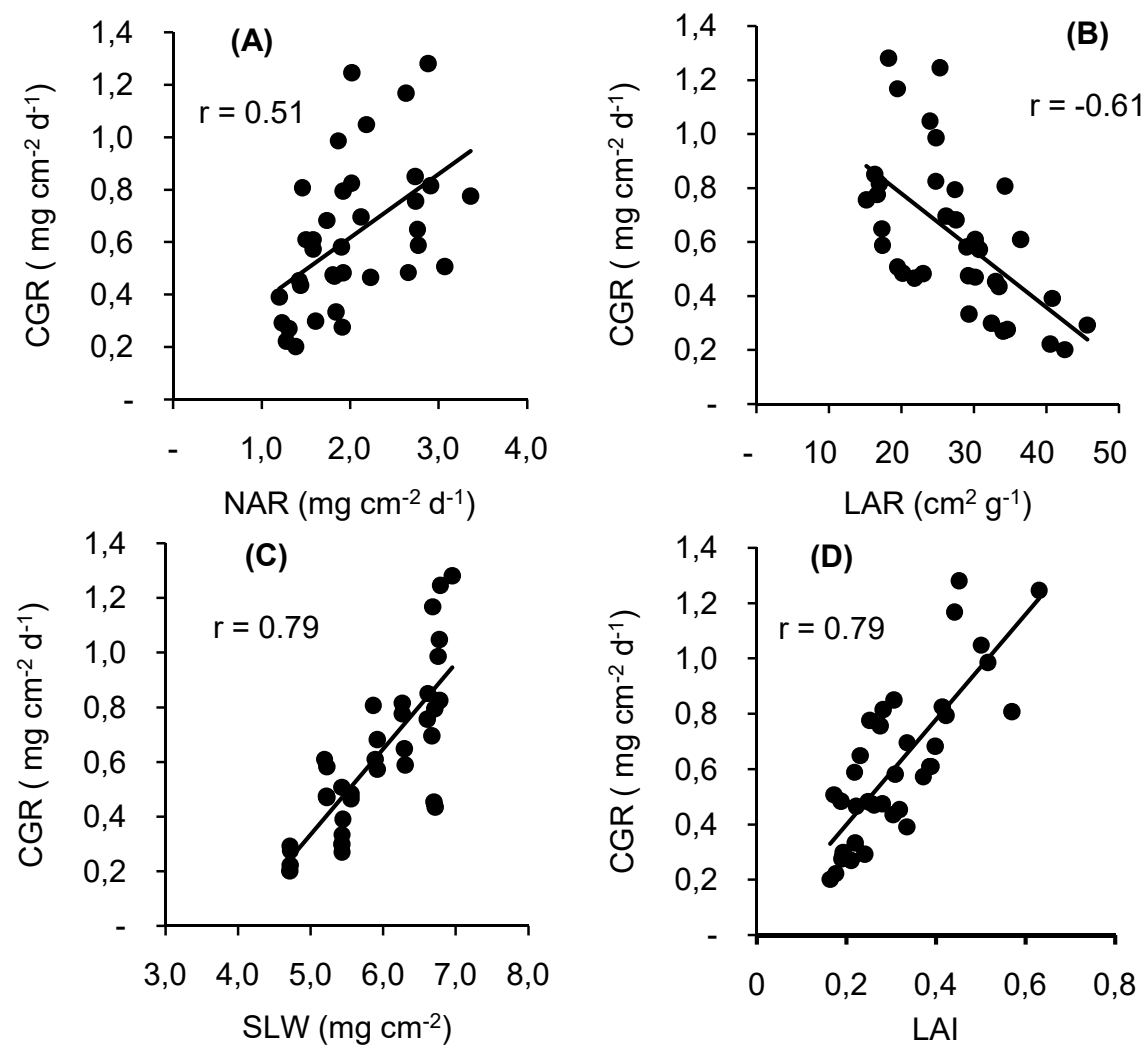

Figure 1 - Correlation of NAR (A), LAR (B), SLW (C), LAI (D) with CGR at 35-42 DAP 
Plant growth was determined by photosynthesis effectiveness for a unit leaf area and total leaves area of each plant. Maximum of total photosynthate was resulted by balancing photosynthesis effectiveness for a unit leaf area and total leaves area. This study showed high CGR of Bima Brebes variety was determined by high LAl, there was a positive correlation between CGR with leaf area increase for each plant. In contrary, Bangkok variety, the highest CGR is determined by higher NAR. Kour and Sharma (2016) explained that CGR increase was a result of photosynthesis activities. CGR increase had strong correlation with NAR, SLW and LAl with $r=0.51 ; r=0.79$ and $r=0.79$ respectively for each, whereas CGR increase had negative correlation with LAR ( $r=-0.61)$ (Figure 1).

Bangkok variety had a higher bulb to leaf dry weight ratio than Bima Brebes and Bauji. Furthermore, there were no differences between Bima Brebes and Bauji, and among different phosphate fertilizer dosages (Table 6). Ratio increase of bulb to leaf dry weight in ideal plant growth environment can be interpreted as bulbs yield increase. However, in this case, the high ratio of the bulb to leaf dry weight to Bangkok variety's had been limited by lower LAR even high NAR (Table 1 and 2). Hence, narrow leaf area was not optimal to support bulbs yield. Fischer et al. (2012) stated that the number and quality of yield required an adequate ratio of leaves and reproductive organ or required certain the number and leaves area.

Table 6 - Bulb to leaf dry weight ratio of three shallot varieties with different phosphate dosages

\begin{tabular}{|c|c|c|c|c|}
\hline \multirow{2}{*}{ Variety $+\mathrm{P}_{2} \mathrm{O}_{5}$} & \multicolumn{4}{|c|}{ Bulb to leaf dry weight ratio } \\
\hline & $21 \mathrm{DAP}$ & $28 \mathrm{DAP}$ & $35 \mathrm{DAP}$ & $42 \mathrm{DAP}$ \\
\hline Bima Brebes + $0 \mathrm{~kg} \mathrm{ha}^{-1}$ & $3.56 \mathrm{~b}$ & $4.08 \mathrm{~b}$ & $4.41 \mathrm{~b}$ & $5.12 \mathrm{c}$ \\
\hline Bima Brebes $+125 \mathrm{~kg} \mathrm{ha}^{-1}$ & $3.84 \mathrm{~b}$ & $4.40 \mathrm{~b}$ & $4.75 \mathrm{~b}$ & $5.58 \mathrm{bc}$ \\
\hline Bima Brebes $+250 \mathrm{~kg} \mathrm{ha}^{-1}$ & $3.51 \mathrm{~b}$ & $4.03 \mathrm{~b}$ & $4.35 \mathrm{~b}$ & $5.03 \mathrm{c}$ \\
\hline Bima Brebes $+375 \mathrm{~kg} \mathrm{ha}^{-1}$ & $3.35 \mathrm{~b}$ & $3.85 \mathrm{~b}$ & $4.15 b$ & $4.88 \mathrm{c}$ \\
\hline Bauji $+0 \mathrm{~kg} \mathrm{ha}^{-1}$ & $2.93 \mathrm{~b}$ & $3.36 \mathrm{~b}$ & $3.63 \mathrm{~b}$ & $4.14 \mathrm{c}$ \\
\hline Bauji $+125 \mathrm{~kg} \mathrm{ha}^{-1}$ & $2.79 \mathrm{~b}$ & $3.20 \mathrm{~b}$ & $3.45 \mathrm{~b}$ & $3.84 \mathrm{c}$ \\
\hline Bauji $+250 \mathrm{~kg} \mathrm{ha}^{-1}$ & $3.87 \mathrm{~b}$ & $4.44 \mathrm{~b}$ & $4.79 \mathrm{~b}$ & $5.56 \mathrm{bc}$ \\
\hline Bauji $+375 \mathrm{~kg} \mathrm{ha}^{-1}$ & $2.99 \mathrm{~b}$ & $3.43 \mathrm{~b}$ & $3.70 \mathrm{~b}$ & $4.19 \mathrm{c}$ \\
\hline Bangkok + $0 \mathrm{~kg} \mathrm{ha}^{-1}$ & $6.26 a$ & $7.19 \mathrm{a}$ & $7.76 \mathrm{a}$ & $8.54 \mathrm{a}$ \\
\hline Bangkok + $125 \mathrm{~kg} \mathrm{ha}^{-1}$ & $6.19 a$ & $7.11 \mathrm{a}$ & $7.67 \mathrm{a}$ & $8.65 a$ \\
\hline Bangkok $+250 \mathrm{~kg} \mathrm{P}_{2} \mathrm{O}_{5} \mathrm{ha}^{-1}$ & $5.72 \mathrm{a}$ & $6.57 \mathrm{a}$ & $7.09 \mathrm{a}$ & $8.13 \mathrm{a}$ \\
\hline Bangkok $+375 \mathrm{~kg} \mathrm{P}_{2} \mathrm{O}_{5} \mathrm{ha}^{-1}$ & $5.43 a$ & $6.23 \mathrm{a}$ & $6.73 \mathrm{a}$ & $7.57 \mathrm{ab}$ \\
\hline HSD $5 \%$ & 1.219 & 1.399 & 1.501 & 2.305 \\
\hline
\end{tabular}

Notes: Numbers followed by different letter at each column are significantly different at $p=0.05$.

Bulbs Yield. Varieties and phosphate fertilizer dosages did not have interaction with the number of bulbs, bulbs diameter, and bulbs weight per hill. They were affected by a single factor. Bangkok had the highest number of bulbs and Bauji had the lowest. Bima Brebes had the highest bulbs diameter and bulbs weight per hill, Bangkok had the lowest bulbs diameter and Bauji had the lowest bulbs weight. Using phosphate fertilizer dosage at $250 \mathrm{~kg} \mathrm{P}_{2} \mathrm{O}_{5} \mathrm{ha}^{-1}$ afforded the highest bulbs number, bulbs diameter, and bulbs weight per hill whereas phosphate fertilizer dosage at $0 \mathrm{~kg} \mathrm{P}_{2} \mathrm{O}_{5}$ ha $^{-1}$ gave the lowest (Table 7).

Table 7 - Yield and yield components of three shallot varieties with different phosphate dosages

\begin{tabular}{|c|c|c|c|}
\hline Treatment & Bulbs number per hill (clove) & Average bulbs diameter $(\mathrm{cm})$ & Bulbs weight per hill (g) \\
\hline Bima Brebes & $4.79 \mathrm{~b}$ & $8.76 \mathrm{a}$ & $19.63 \mathrm{a}$ \\
\hline Bauji & $3.88 \mathrm{c}$ & $8.10 \mathrm{~b}$ & $12.59 \mathrm{c}$ \\
\hline Bangkok & $7.65 \mathrm{a}$ & $6.91 \mathrm{c}$ & $15.90 \mathrm{~b}$ \\
\hline LSD $5 \%$ & 0.431 & 0.328 & 1.744 \\
\hline $0 \mathrm{~kg} \mathrm{P}_{2} \mathrm{O}_{5} \mathrm{ha}^{-1}$ & $5.01 \mathrm{~b}$ & $7.38 \mathrm{~b}$ & $13.69 \mathrm{c}$ \\
\hline $125 \mathrm{~kg} \mathrm{P}_{2} \mathrm{O}_{5} \mathrm{ha}^{-1}$ & $5.42 a b$ & $7.66 \mathrm{~b}$ & $15.47 \mathrm{bc}$ \\
\hline $250 \mathrm{~kg} \mathrm{P}_{2} \mathrm{O}_{5} \mathrm{ha}^{-1}$ & $5.79 a$ & $8.41 \mathrm{a}$ & $18.09 \mathrm{a}$ \\
\hline $375 \mathrm{~kg} \mathrm{P}_{2} \mathrm{O}_{5} \mathrm{ha}^{-1}$ & $5.53 \mathrm{a}$ & $8.24 a$ & $16.91 \mathrm{ab}$ \\
\hline LSD 5\% & 0.497 & 0.379 & 2.014 \\
\hline
\end{tabular}

Note: Numbers followed by different letter at each column are significantly different at $p=0.05$. 

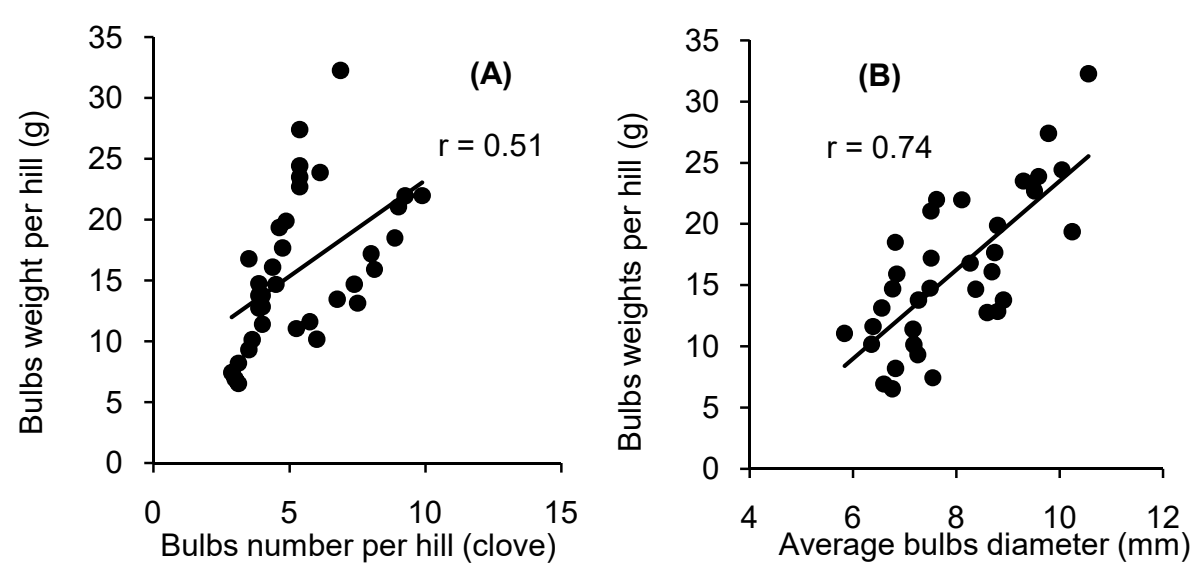

Figure 2 - Correlation of bulbs number $(A)$ and bulbs diameter $(B)$ with bulbs weight per hill

A number of bulbs and diameter of bulbs were components that influenced to bulbs weight per hill, had a strong correlation between them shown with $r=0.51$ and $r=0.74$ $(p<0.01)$ for each respectively (Figure 2). High bulbs weight of Bima Brebes was influenced by high bulbs diameter. Although Bangkok had the highest number of bulbs; the bulbs weight was lower than Bima Brebes. Low bulbs weight of Bangkok showed high NAR was not followed by LAR and LAI increase. It caused photosynthate for translocation to shallot bulbs not maximum, so bulbs diameter was lower. Li et al. (2016) said an increase of NAR and total leaves area would escalate capacity source and bulbs yield. Fischer et al. (2012) explained photosynthate translocation from leaves was essential for sink growth and development, number and quality of yield relied on an adequate source and sink relationship. Alizadeh et al. (2013) found photosynthesis increase was required by a sink, and sink needs to be accumulated at early reproductive phase. Low bulbs weight per hill Bauji had because of a little number of bulbs, high LAR, and low CGR. It means photosynthate partition of leaves used for leaves area increased more than other organs' growth includes bulbs. Weraduwage et al. (2015) added the increase of new leaf part, leaves mass, roots mass, and the reproductive organ was depended on the direction of photosynthate partition.

High bulbs weight per hill that Bima Brebes had and fertilization with phosphate at 250 $\mathrm{kg} \mathrm{P}_{2} \mathrm{O}_{5}$ ha $^{-1}$ dosage were supported by high LAI and CGR. In contrast, low bulbs weight per hill that Bauji had and fertilization with phosphate at $0 \mathrm{~kg} \mathrm{P}_{2} \mathrm{O}_{5} \mathrm{ha}^{-1}$ dosage were the results of low LAl and CGR. Khayat et al. (2015) explained that high LAl at maximum growth phase had a positive correlation with yield and low LAl could stimulate yield decreased. Pandey et al. (2015) found LAl and CGR had a positive correlation with yield. In addition, phosphate fertilization increased biomass and yield while plant which had a lack of phosphate decreased yield.

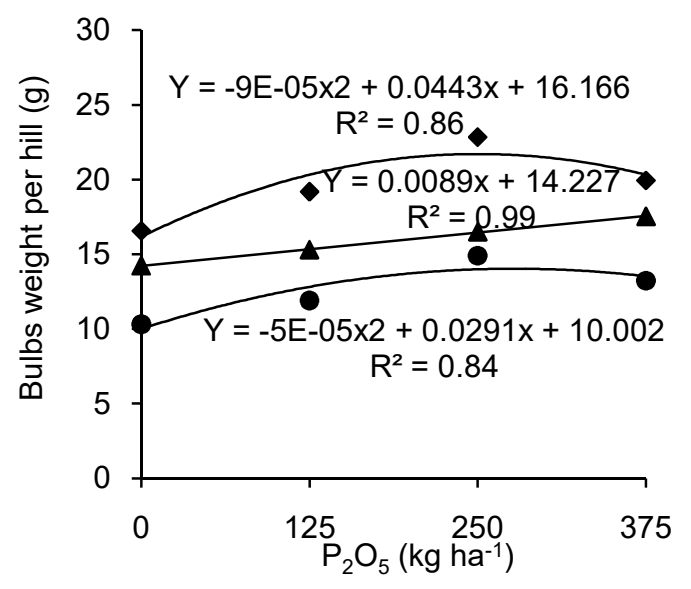

Figure 3 - Relationship of phosphate dosages and bulbs weight per hill $(\bullet=$ Bima Brebes; $\bullet$ = Bauji; $\boldsymbol{\Lambda}=$ Bangkok $)$. 
The optimum dosages of phosphate fertilizer required of each variety were different. Bima Brebes required $246.11 \mathrm{~kg} \mathrm{P}_{2} \mathrm{O}_{5}$ ha $^{-1}$ for bulbs weight $21.62 \mathrm{~g}$ per hill; Bauji required $291.00 \mathrm{~kg} \mathrm{P}_{2} \mathrm{O}_{5}$ ha $^{-1}$ for bulbs weight $14.24 \mathrm{~g}$ per hill. Bangkok showed a linear increase of bulbs weight per hill up to $375 \mathrm{~kg} \mathrm{P}_{2} \mathrm{O}_{5}$ ha $^{-1}$ (Figure 3). In conclusion, Bima Brebes has the highest bulbs weight per hill with the most efficient phosphate fertilizer used. Sopha et al. (2015) found the efficiency of fertilizer used was influenced by shallot varieties. Li et al. (2016) added nutrient controlled source-sink relationship determined yield.

\section{CONCLUSION}

Characteristics of growth and yield affected by shallot varieties and different phosphate dosages. Bangkok variety had the highest NAR, SLW, bulb to leaf dry weight ratio, and bulbs number. Bima Brebes had the highest LAI, CGR, bulbs diameter, and bulbs weight whereas Bauji had the highest LAR. Optimum dosage of phosphate was different for each variety. The dosage of $375 \mathrm{~kg} \mathrm{P}_{2} \mathrm{O}_{5}$ ha $^{-1}$ at Bangkok showed a linear increase of bulbs weight while Bima Brebes reached the highest weight as much as $21.62 \mathrm{~g}$ per hill at an optimum dosage of $246.11 \mathrm{~kg} \mathrm{P}_{2} \mathrm{O}_{5} \mathrm{ha}^{-1}$.

\section{ACKNOWLEDGEMENTS}

We thank Head Department of Agriculture and Horticulture Main Seed Development Centre Muaro Jambi for all of the infrastructures, facilities, and field workers provided to conduct this research.

\section{REFERENCES}

1. Agricultural Information System Data Center (2015). Shallots outlook. Jakarta: The Ministry of Agriculture.

2. Alizadeh, O., Farsinejad, K., Korani, S., \& Azarpana, A. (2013). A study on a source-sink relationship, a photosynthetic ratio of different organs on yield and yield components in bread wheat (Triticum aestivum L.). International Journal of Agriculture and Crop Sciences, 5(1), 69-79.

3. Bugbee, B. G. (1996). Growth analysis and yield components. In F.B. Salisbury (Ed.), Units, symbols, and terminology for plant physiology: A reference for presentation of research results in the plant sciences (pp. 115-119). New York: Oxford University Press.

4. Fischer, G., Merchan, P. J. A., \& Ramirez, F. (2012). Source-sink relationships in fruit species: A review. Revista Colombiana De Ciencias Horticolas, 6(2), 238-253.

5. General Directorate of Horticulture (2015). Horticultural Production Statistics 2014. Jakarta: The Ministry of Agriculture.

6. Hochberg, U., Batushansky, A., Degu, A., Rachmilevitch, S., \& Fait, A. (2015). Metabolic and physiological responses of shiraz and cabernet sauvignon (Vitis vinifera L.) to near optimal temperatures of 25 and $35{ }^{\circ} \mathrm{C}$. International Journal of Molecular Sciences, 16(10), 24276-24294.

7. Idhan, A., Syam'un, E., Zakaria, B., \& Riyadi, M. (2015). Potential selection of flowering and tuber production in fourteen onion varieties (Allium ascalonicum L.) at lowland and upland. International Journal of Current Research in Biosciences and Plant Biology, 2(7), 63-67.

8. Khayat, M., Rahnama, A., Lorzadeh, S., \& Lack, S. (2015). Growth analysis rapeseed (Brassica napus L.) genotypes in different sowing date under warm and semiarid climate condition in South West of Iran. Journal of Biodiversity and Environmental Sciences, 6(1), 387-394.

9. Kour, R. \& Sharma, B. C. (2016). Study of physiological growth indices of mustard in chickpea (Cicer arietinum) + mustard (Brassica juncea) intercropping system under different weed management practices. Indian journal of agricultural research, 50(2), 139145. 
10. Li, W., Xiong, B., Wang, S., Deng, X., Yin, L., \& Li, H. (2016). Regulation effects of water and nitrogen on the source-sink relationship in potato during the tuber bulking stage. PLoSONE, 11(1), e0146877.

11. Mojaddam, M. \& Noori, A. (2015). The effect of sowing date and plant density on growth analysis parameters of cowpeas. Indian Journal of Fundamental and Applied Life Sciences, 5(1), 224-230.

12. Pandey, R., Khetarpal, S., Jain, V., \& Kushwaha, S. R. (2015). Phosphorus fertilization improves growth analysis traits and reduces anthesis-to-silking interval leading to increased grain yield in maize. Indian Journal of Plant Physiology, 20(4), 385-390.

13. Pankaj, S. C, Sharma, P. K., Chouksey, H. D., \& Singh, S. K. (2015). Growth and development pattern of barley varieties as influenced by date of sowing and nitrogen levels. The Bioscan, 10(3), 1299-1302.

14. Rashmi, I., Biswas, A. K., Parama, V. P. R., \& Rao, A. S. (2015). Phosphorus sorption characteristics of some representative soils of south India. SAARC Journal of Agriculture, 13(1), 14-26.

15. Simon, T., Tora, M., Shumbulo, A., \& Urkato, S. (2014). The effect of variety, nitrogen and phosphorous fertilization on growth and bulbs yield of onion (Allium Cepa L.) at Wolaita, Southern Ethiopia. Journal of Biology, Agriculture and Healthcare, 4(11), 89-97.

16. Sopha, G. A., Rosliani, R., Basuki, R. S., Liferdi, L., \& Yufdy, M. P. (2015). Correlation of plant nutrients uptake with shallot production in alluvial soils. Advances in Agriculture \& Botanics- International Journal of the Bioflux Society, 7(2), 127-137.

17. Sridevi, V. \& Chellamuthu, V. (2015). Growth analysis and yield of rice as affected by the different system of rice intensification (SRI) Practices. International Journal of Research in Applied, Natural and Social Sciences, 3(4), 29-36.

18. Sumarni, N., Rosliani, R., Basuki, R. S., \& Hilman, Y. (2012). The response of shallot to phosphate fertilization on some soil fertility levels (P-soil status). Jurnal Hortikultura, 22(2), 130-138.

19. Weraduwage, S. M., Chen, J., Anozie, F. C., Morales, A., Weise, S. E., \& Sharkey, T. D. (2015). The relationship between leaf area growth and biomass accumulation in Arabidopsis thaliana. Frontiers in Plant Science, 6(167), 1-21. 